\title{
P-44 MIOCENE CARBONATE-FRINGED - BASINS OF SOUTH CENTRAL TURKEY - CORRELATION, EVOLUTION \& CONTROLS
}

\begin{abstract}
Summary
Studies of sequence, sedimentology and structure in four Oligo-Miocene basins in southern Anatolia reveal broadly similar, but diachronous, patterns of evolution that include a significant phase of marginal reef-carbonate development early in the Miocene history of each basin. These carbonates accumulated during periods of probably eustatic transgression and highstand but reef growth and carbonate deposition continued during the early stages of tectonically enhanced coarse clastic supply and concomitant basin subsidence, attesting to highly efficient bypass mechanisms on basin-margins. The observed minor differences and diachronaeity in basin histories reflect changes in the geodynamic setting of the basins as a result of progressive Arabian-Anatolian collision during the Miocene.
\end{abstract}

\section{Introduction}

During the Oligo-Miocene interval in southern Anatolia (Turkey) closure of the southern branch of Neo-Tethys was accompanied by creation of a series of supra-sutural basins. Most of these basins (flanked to the north by the emerging Tauride chain) were extensional in nature and display broadly similar tectono- stratigraphic characters but they also exhibit subtle differences in depositional style and geotectonic setting. While these basins were predominantly filled by siliciclastic sediments, each basin was bordered by narrow carbonate shelves or ramps at some stage in their evolution.

The main stratigraphic and sedimentological features of four of these basins are outlined below, together with brief accounts of the correlative events that can be recognised in the fill sequences. Factors (sediment supply, local and regional tectonics, eustasism, etc.) controlling the evolution of these basins are briefly discussed. These four basins comprise (from west to east) the Mut Basin(1), Adana Basin (2), Misis- Andirin Trough (3) and the Maras Basin (4) (see Fig.1). This synthesis derives from the work of many people, including Turkish and British colleagues and former students of the author, to all of whom I am much indebted.

\section{Summary of Basin Fill Sequences}

\section{MUT BASIN:}

The Tertiary sequence here rests unconformably upon a deformed basement of Tauride nappes comprising ophiolite bodies and Mesozoic platform carbonates. The post-orogenic succession commences with fluvial redbeds that pass vertically and laterally into dark-hued coarse turbidites and ostracod-rich marls (sub-lacustrine fan), succeeded by shallow lacustrine sands, silts and thin calcisiltites. The latter deposits are replaced upwards by a widespread unit of buff to white lacustrine calcilutites and calisiltites, containing wedges of redbeds and lagoonal clays near the top. This entire succession was previously considered to be Eocene, but recent analyses of abundant microfaunas demonstrate that the lower redbeds and lacustrine turbidites are Early Oligocene while the succeeding lacustrine to lagoonal carbonates are Late Oligocene to basal Miocene (Aquitanian) in age.

The overlying Miocene succession commences with coarse alluvial fan and fluvial redbeds that infill a pre-existing, high-relief paleotopography. Locally these redbeds rest discordantly on tilted and warped Late Oligocene carbonates but elsewhere they overlap the Oligocene rocks to rest directly upon the Tauride basement. This redbed sequence is of Burdigalian age and thin marine intercalations appear 


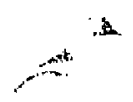

near the top. These clastics pass laterally and vertically into a thick carbonate dominated sequence (littoral to shallow marine) that also transgresses directly on Tauride basement around the basin margins.

The lower of these carbonate units (late Burdigalian to Langhian in age) comprises marls, mudstones and limestones and includes numerous patch-reefs that become larger and more common upwards, marking the passage into the thick Mut Limestone Formation, spanning the late Burdigalian to late Serravallian or early Tortonian interval. Prograding bodies of calcareous sandstone and pebble/cobble conglomerate occur both within this thick, reef-dominated carbonate unit and the underlying marls with patch-reefs. Large-scale clinoform architecture is characteristic of these carbonate-dominated units. No later Miocene or Pliocene units occur within this basin, but Upper Miocene clastics with thin marine limestones and Early Pliocene lacustrine clastics and limestones occur to the north, in the Karaman area.

\section{ADANA BASIN:}

The succession in the northern part of this basin is broadly similar to that seen in Mut. In the Karsanti sub-basin alluvial redbeds and lacustrine clastics of mid to late Oligocene age rest unconformably on Tauride nappe basement. These are succeeded discordantly by early Miocene alluvial fan and delta fan sandstones and rudites that interfinger with shallow marine clastics and pass upwards into a thick early to middle Miocene sequence of reefal and platform carbonates displaying clinoform architecture, together with slope deposits of mixed clastic and carbonate composition. In central and southern parts of the basin the mid-Miocene carbonates pass laterally and vertically into a thick sequence of sandy turbidites, depossited in at least two small, overlapping submarine fans. Within the Serravallian these turbidites shoal upwards into storm-dominated shelf clastics, disconformably succeeded by a Tortonian sequence of fluvio-deltaic sands (with a 10-15m thick tuffite) and a Messinian succession dominated by shallow marine and lagoonal clastics, thin limestones and gypsum beds.

\section{MISIS-ANDIRIN COMPLEX:}

In contrast to the western basins, this region has undergone significant post-Miocene deformation, including tilting and thrust-stacking of the Neogene succession. Careful biostratigraphic zonation, however, has enabled the broad stratigraphic pattern to be established.

No in situ basement is seen here. The oldest Tertiary formation (Chattian-Aquitanian) is a thick chaotic unit or olistrostromic complex, comprising a matrix of volcanogenic sandstone and shale carrying large and small blocks of ophiolite,

basaltic volcanics and Mesozoic platform carbonates. This is tectonically separated from a thick sequence of deep marine, distal turbidite sandstones and pelagic marls of Burdigalian to late SerravalLian age, interleaved near the top with wedges of shelf clastics and biostromal limestones. The highest Miocene units seen here are Tórtonian clastics of fluvio-deltaic character, with thin lagoonal and paralic interbeds.

\section{MARAS BASIN:}

This E-W elongated basin, north of the city of Kharamanmaras, displays a thick, slightly deformed Miocene succession which in the north rests discordantly upon Tauride nappe units, but further south follows concordantly on shelf limestones of Eocene-Oligocene age (Midyat Formation). In the north, the Miocene commences with thin neritic calcarenites, marls and clinoformal reefal limestones of late Aquitanian to Burdigalian age (Fig. 5). The carbonates wedge out southwards into a thick sequence of coeval slope and basinal muddy turbidites that coarsen upwards and extend northwards with time. By late Langhian/ early Serravallian three major feeder channels filled with coarse sands and gravels can be identified, two of which eroded deep submarine canyons through the narrow carbonate belt flanking the northern margin of the basin. Further south the youngest turbidites are discordantly succeeded by a thick series of fluvio-deltaic clastics of upper Miocene age. 


\section{Comparison of Basin Histories}

The sequences of the Mut and Adana Basins (and the intervening Ecemis Fault zone) reveal an Oligocene history of intra-montane depocentres, created on a newly uplifted Tauride topography, with early and localised subsidence promoting the growth of large lakes that subsequently shallowed through infilling by both clastic and carbonate sediments. These lakes were evidently deeper in Mut, permitting growth of lake-floor turbidite bodies and distinctive slope facies. Sediment transport (of almost exclusively Tauride detritus) was dominantly from $\mathrm{N}$ and NW during the Oligocene in both basins. The first, tentative, marine incursion occurred in the earliest Miocene in both basins but was quickly followed by a late Aquitanian/early Burdigalian tectonic episode. This involved fault-mediated tilting and warping of the Oligocene deposits and creation of a high relief palaeotopography that was quickly infilled by coarse Burdigalian redbeds.

The early Miocene marine transgression resumed in the mid to late Burdigalian in both basins and was initially accompanied by a decrease in coarse detrital supply, leading to the creation of wide carbonate ramps and, eventually, to patch-reef dominated shelves. A further phase of tectonic subsidence (probably controlled by reactivation of NE-SW border faults) in the basal Langhian led to differentiation of narrow northern carbonate rims from deeper basins to the south. This subsidence was dramatically greater in the Adana Basin, giving rise to the great thickness of mid Miocene deep marine shales and submarine fan deposits there. Interestingly, great volumes of coarse clastic material were supplied to the deep Adana Basin (through deep conduits cut into coeval shelf sediments) during the acme of reef carbonate growth. The limestone-dominated marginal sequences in both these western basins display clinoformal architecture and the cyclical facies arrangements characteristic of parasequences, attesting to sea-level oscillations during the middle Miocene 'highstand'. A general reduction in subsidence and consequential upward shoaling is evident in the late Serravallian, even in the deeper parts of the Mut and Adana basins. In the early and mid Miocene of both basins the main clastic supply (from Tauride orogenic units and penecontemporaneous deposits) was from N and NW. Late Miocene fluviodeltaic and paralic sequences mark a return to more continental conditions and in Adana they rest upon a tectonic disconformity. Here, the Tortonian fluvio-deltaics were supplied from NE and are compositionally more diverse than earlier Miocene sediments.

By contrast, in the eastern basins the late Oligocene deposits are mainly marine, including the shelf limestones of the southern Maras Basin and the chaotic mass flows of the Misis-Andirin trough. The succeeding sequences here are also mainly marine and of relatively deep shelf to basin floor character, reflecting rapid subsidence and enhanced clastic supply during the basal Miocene (earlier than in the western basins). Coeval fringes of reefal and coquinoid carbonates also developed earlier along the northern margin of the Maras basin (late Aquitanian/early Burdigalian): Paleoflow in the early Miocene turbidites and shelfal clastics of the Maras basin was mainly from $\mathrm{N}$ and NNE, while supply of coeval deposits to the Misis-Andirin trough was dominantly from NE, with subordinate influxes from NW. Marked sea-level oscillations in the mid-Miocene are evident in the marginal facies within both basins. In both eastern basins there is evidence for a late Miocene (? late Serravallian) tectonic episode that was succeeded by an influx from NE of coarse fluvio-deltaic clastics.

\section{Conclusions:}

1. During the Oligocene the two western basins were sites of continental and lacustrine deposition undergoing subsidence in response to mountain-front tectonics, while the eastern basins occupied more stable marine-margin settings.

2. During the Miocene all the basins display a comparable pattern of evolution, with early marine transgression, promoting the formation and expansion of carbonate fringes, followed by rapid subsidence and enhanced clastic supply that led to accumulation of thick deepwater deposits, all abruptly terminated by Tortonian tectonic reorganisation and the advance of major deltaic complexes from $\mathrm{NE}$ and $\mathrm{N}$.

3. These changes appear to have been broadly diachronous, with the major early Miocene transgression, the inception of subsidence and enhanced clastic supply and the tectonic termination of fully marine deposition occurring earlier in the east.

4. Early and middle Miocene sedimentation in the western basins was influenced by short-period fluctuations in relative sea-level (not so evident in the eastern basins) that may reflect global (eustatic) phases of transgression and highstand. 
5. However, reef-carbonates continued to accumulate and expand during the early stages of tectonically enhanced clastic supply and increased basinal subsidence, primarily through highly efficient bypassing of coarser detritus across marginal ramps, narrow shelves and steep slopes.

6. In terms of geotectonic setting the western basins (Mut and Adana) can be considered inboard and the eastern basins (Misis and Maras) outboard with respect to the southern Neotethyan active margin. The subtle differences in basin evolution and the tectono-stratigraphic diachronaeity noted above are consistent with oblique collision of the Arabian and Anatolian plates during the Miocene.

Fig. 1 Caption: Outline geological map of the NE Mediterranean, showing location of the 4 Neogene basins described in the text: 1. Mut Basin; 2. Adana Basin; 3. Misis-Andirin Complex (M-A C); 4. Maras Basin. DSF - Dead Sea Fault; EAFEast Anatolian Fault; EF - Ecemis Fault; KB - Karsanti sub-basin; KM -

KharamanMaras; KR - Kyrenia Ridge. Bathymetric contours shown in metres.

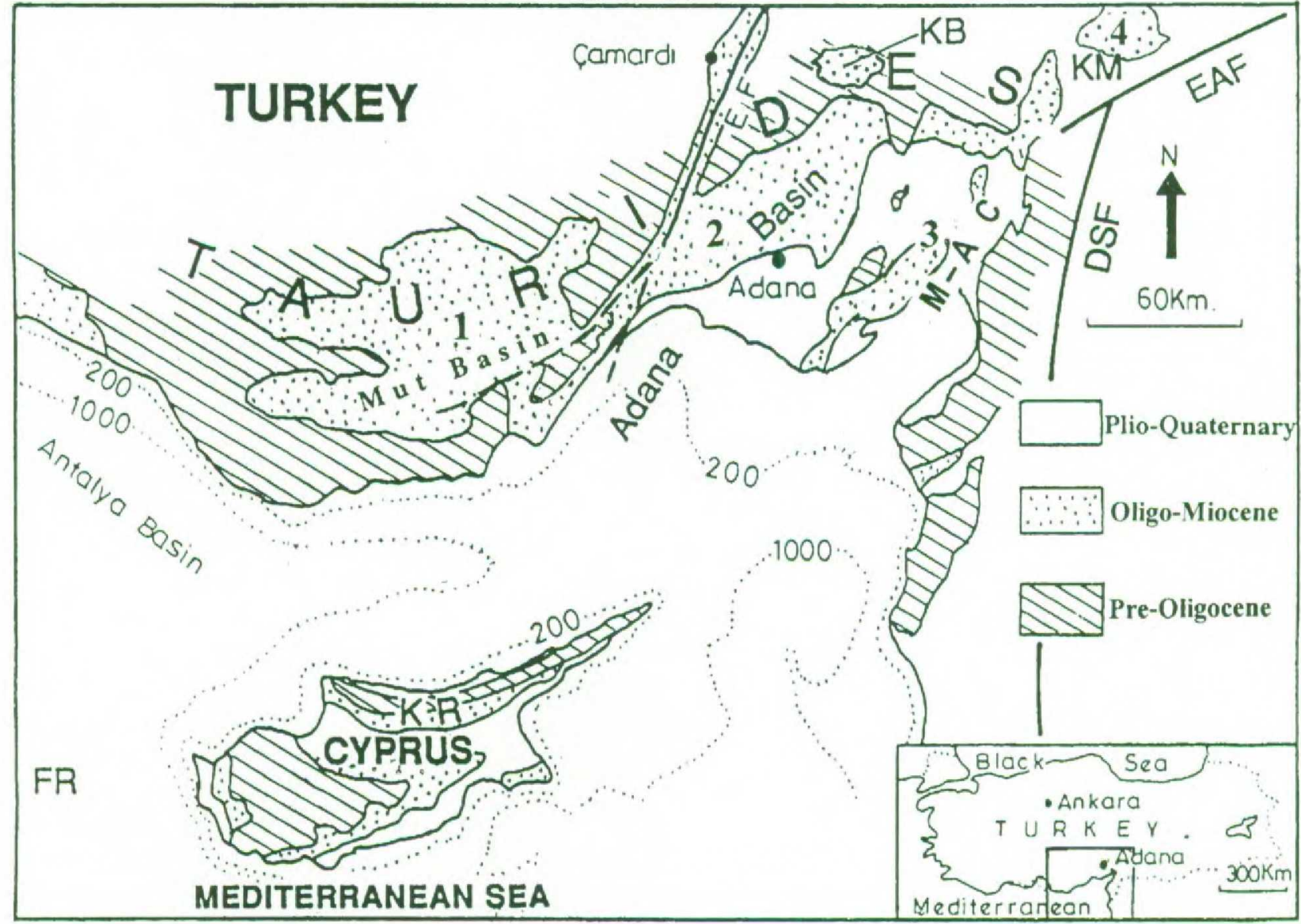

